\title{
THE GENETICS OF THE INSULARIA FORMS OF THE PEPPERED MOTH, BISTON BETULARIA
}

\author{
D. R. LEES and E. R. CREED \\ Department of Zoology, University College, Cardiff
}

Received 8.xi.76

\begin{abstract}
SUMMARY
Insularia is a complex of forms in $B$. betularia ranging continuously between the paler, typical form and the black carbonaria. It appears that at least three alleles at the same locus as carbonaria control the insularia forms. Carbonaria is dominant to all insularia and to typical. The insularia forms show incomplete dominance; individuals carrying two insularia alleles are usually darker than corresponding insularia/typical heterozygotes.
\end{abstract}

\section{INTRODUCTION}

DesPite the attention paid to industrial melanism generally, and to Biston betularia in particular, the range of forms known as insularia in this species has been little studied. In appearance insularia is intermediate between the pale, typical form and the extreme melanic form, carbonaria. It reaches frequencies as high as 50 per cent in parts of South Wales (Lees and Creed, 1975), and Holland (B. Lempke in litt. and in Kettlewell, 1973): even higher frequencies are found in parts of Scandinavia (Douwes et al., 1973).

Previous work on the genetics of insularia has shown that both a form from the middle of the range from Oxford (Clarke and Sheppard, 1964) and a slightly darker, though not extreme, form from Herefordshire (Lees, 1968) are controlled by alleles at the carbonaria locus with carbonaria dominant to insularia which is, in turn, dominant to the typical form. Earlier, Lemche (1931), working with Danish material, had shown that the most probable interpretation of segregations in families reared by him was that a light form of insularia was allelic with doubledayaria (= carbonaria). Glose examination of his plate VI, however, reveals that what he scored as doubledayaria were in fact very dark insularia. This inadvertent discovery is the only previous work into the genetic relationship of different insularia forms. The investigation reported here deals, in the main, with the genetics of insularia at the light and the dark extremes of what Kettlewell (1973) has termed the "insularia complex", both in relation to each other and to carbonaria, although the middle of the range of forms is also discussed.

\section{SCORING}

The "insularia complex" includes individuals almost as pale as typical at one extreme and as dark as carbonaria at the other (see plate I). Among lighter insects the presence of a predominantly black abdomen has been found to be characteristic of insularia whereas typical, with few exceptions, have a distinctly white abdomen with some black markings. The patterning of the wings in light insularia presents a more even speckling of black and 
white scales than in typical, where the scales are so arranged as to present the appearance of black lines and patches on a white background. This scoring conflicts with Kettlewell (1973), whose two palest insularia categories would be scored by us, and also by Steward (1977) as typical; in Douwes et al. (1973) we would regard their fig. IC to bc typical and ID to be $\mathrm{I}^{\mathbf{1}}$.

At the other extreme, dark insularia have been distinguished from carbonaria by the presence of a fine speckling of white scales on an otherwise black forewing. Those moths with a distinct line of white scales running transversely across both fore- and hind-wings, but lacking a general speckling of white scales, have been scored as carbonaria, as they have in Steward's (1977) analysis. This form, which is phenotypically identical with Kettlewell's (1958) " ancient heterozygotes", occurs, especially among males, in some families involving carbonaria and typical where insularia is not present.

Within South Wales populations, it is possible to classify the insularia phenotype "by eye" into three, rather arbitrary, categories, each representing an approximately equal proportion of the total variation. In increasing order of darkness these categories are referred to here as $\mathrm{I}^{1}, \mathrm{I}^{2}$ and $\mathrm{I}^{3}$; we are mainly concerned with the genetic relationship of $\mathrm{I}^{1}$ and $\mathrm{I}^{3}$. In families involving segregation of $\mathrm{I}^{1}$ and $\mathrm{I}^{3}$, no difficulty has been encountered in attributing any insect to either of the categories $\mathrm{I}^{1}$ or $\mathrm{I}^{3}$ or to $\mathrm{T}$ and $\mathrm{C}$. There is, however, some difficulty in distinguishing $\mathrm{I}^{2}$ from $\mathrm{I}^{1}$ and $\mathrm{I}^{2}$ from $\mathrm{I}^{3}$ when the moths are scored subjectively. However, Steward (1977), using a more objective Discriminant Function Analysis confirms that there is justification for separating insularia into three categories, although his P, M and D insularia categories do not closely correspond with $\mathrm{I}^{1}, \mathrm{I}^{2}$ and $\mathrm{I}^{3}$ here. As Steward emphasises, his PI category contains over half of the total variation in insularia; PI therefore contains some of $\mathrm{I}^{2}$ as well as all of $\mathrm{I}^{1}$. MI would then correspond with the remainder of $\mathrm{I}^{2}$ and some $\mathrm{I}^{3}$ while DI and the rest of $\mathrm{I}^{3}$ appear to be more or less equivalent (see fig.).

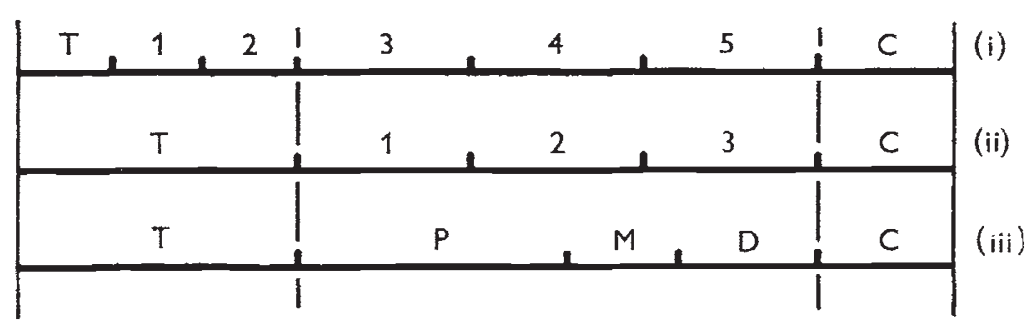

FIG.-Diagrammatic representation of the range of variation in Biston betularia, indicating a comparison of three scoring methods: (i) Kettlewell (1973); (ii) this study; (iii) Steward (1977). The variable should not be taken as darkness, since some typicals may be considerably darker than pale $\mathbf{I}^{\mathbf{1}}$.

\section{Materials and methods}

Apart from female parents of the 1972 families, which were from Oxford stock, all of the material used to investigate $\mathrm{I}^{3}$ and $\mathrm{I}^{1}$ is of South Wales origin. In thus restricting the origin of parents it was hoped to avoid any scoring complications due to breakdown of dominance in an alien gene complex, such as that shown with carbonaria by Kettlewell (1965). The 


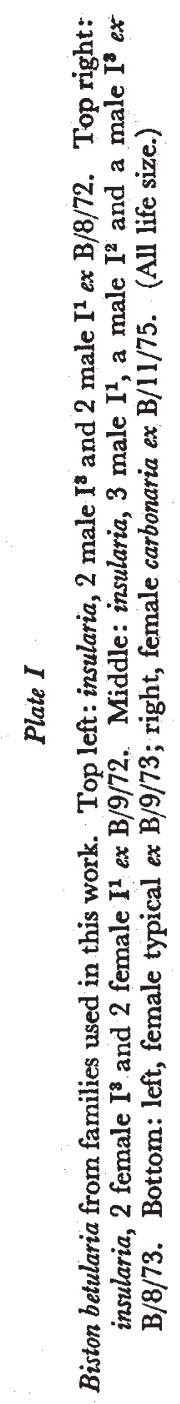



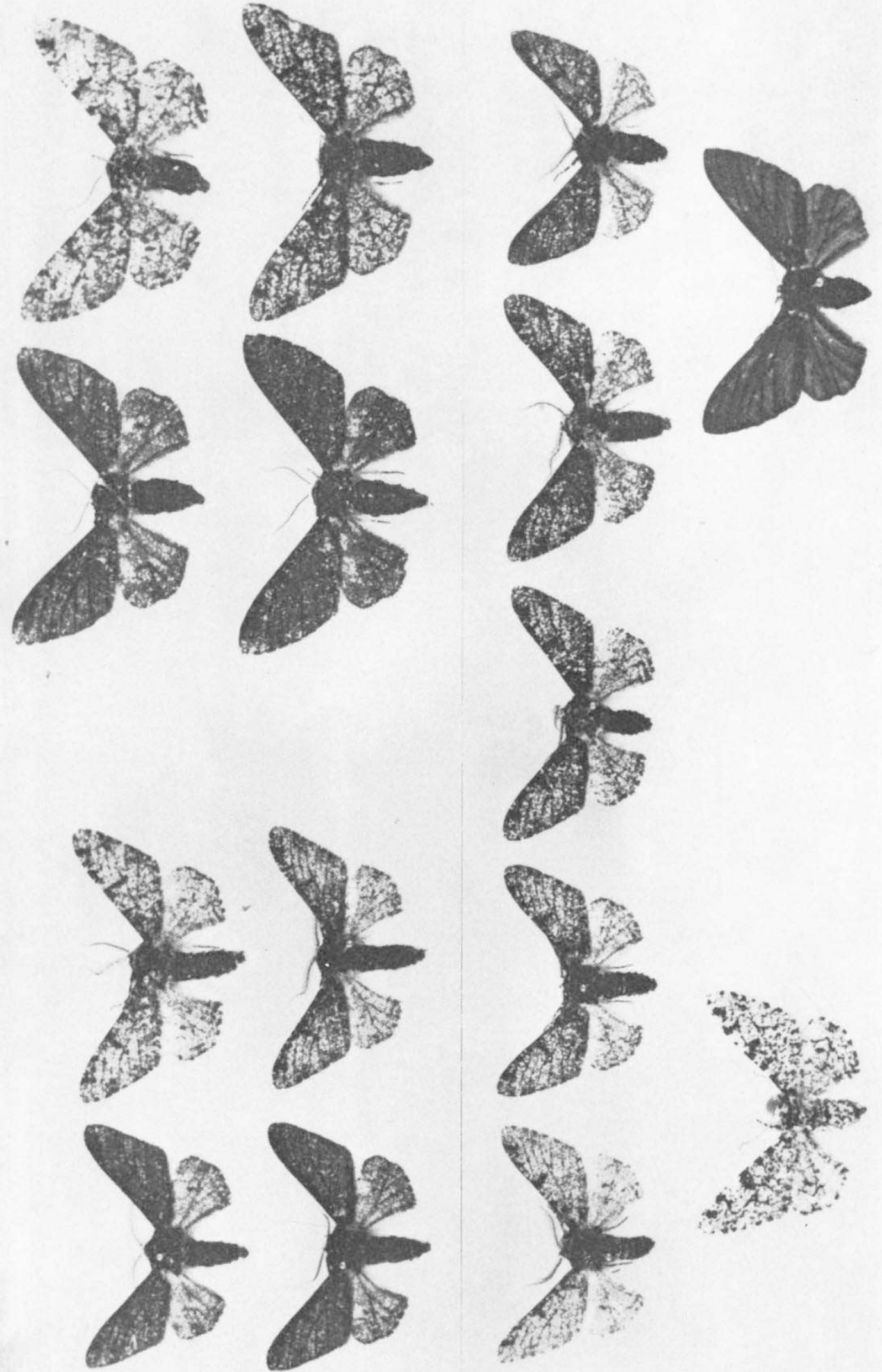
material used to examine the $\mathrm{I}^{1} / \mathrm{I}^{2}$ relationship is more varied, involving crosses of Oxford $\times$ Oxford and Oxford $\times$ South Wales material.

The majority of the families were reared in the laboratory in cages constructed of wood and nylon gauze using sallow (Salix spp.) as the larval food plant. Care was taken to prevent larval mortality from disease or starvation which, if selective, would affect the segregation ratios. The few remaining families were reared, with similar precautions, out of doors in polyester gauze sleeves over sallow bushes.

\section{Results}

(i) Genetic relationship of $I^{3}$ and $I^{1}$

Table 1 contains details of the parentage and progeny of the crosses used to establish the relationship between $\mathrm{I}^{3}$ and $\mathrm{I}^{\mathbf{1}}$.

TABLE 1

Families of Biston betularia used to examine the relationship of $I^{3}$ amd $I^{1}$

\begin{tabular}{|c|c|c|c|c|c|c|c|c|}
\hline \multirow[b]{2}{*}{ Family } & \multicolumn{2}{|c|}{ Parents } & \multicolumn{5}{|c|}{ Progeny } & \multirow[b]{2}{*}{ Total } \\
\hline & Male & Female & $\mathrm{T}$ & 1 & 2 & 3 & C & \\
\hline $\mathrm{B} / 1 / 72$ & T ex Cardiff & $\mathrm{C} e \times \mathrm{B} / 3 / 71$ & 134 & & & & 123 & 257 \\
\hline $\mathrm{B} / 8 / 72$ & $I^{3}$ ex Beddau & $\mathrm{T}$ ex Oxford & & 21 & & 27 & & 48 \\
\hline $\mathrm{B} / 9 / 72$ & $\mathrm{I}^{3}$ ex Beddau & T ex Oxford & & 34 & & 25 & & 59 \\
\hline $\mathrm{B} / 1 / 73$ & $\mathrm{I}^{3}$ ex $\mathrm{B} / 9 / 72$ & $\mathrm{~T}$ ex $\mathrm{B} / 1 / 72$ & 59 & & & 48 & & 107 \\
\hline $\mathrm{B} / 2 / 73$ & $\mathrm{I}^{3}$ ex $\mathrm{B} / 8 / 72$ & $\mathrm{~T}$ ex $\mathrm{B} / 1 / 72$ & 92 & & & 72 & & 164 \\
\hline $\mathrm{B} / 4 / 73$ & $\mathrm{I}^{3}$ ex $\mathrm{B} / 8 / 72$ & $\mathrm{~T}$ ex $\mathrm{B} / \mathrm{l} / 72$ & 70 & & & 62 & & 132 \\
\hline $\mathrm{B} / 7 / 73$ & $I^{1}$ ex Beddau & $\mathrm{I}^{3}$ ex B/8/72 & 66 & 55 & & 135 & & 256 \\
\hline $\mathrm{B} / 9 / 74$ & $\mathrm{I}^{1}$ ex Beddau & $\mathrm{T}$ ex B/4/73 & 88 & 56 & 25 & & & 169 \\
\hline
\end{tabular}

Both $\mathrm{B} / 8 / 72$ and $\mathrm{B} / 9 / 72$ are families whose male parents were phenotypically $\mathrm{I}^{3}$ and which came from Beddau, which lies about $16 \mathrm{~km} \mathrm{NW}$ of Cardiff. Both were crossed to typical females from Oxford stock and among the progeny of both families a $1: 1$ segregation of $\mathrm{I}^{3}: \mathrm{I}^{1}$ resulted.

This segregation is explicable in either of two simple ways: either $(a) \mathrm{I}^{3}$ and $\mathrm{I}^{1}$ are controlled by alleles at the same locus with $\mathrm{I}^{3}$ dominant to $\mathrm{I}^{1}$, or (b) $\mathrm{I}^{\mathbf{3}}$ and $\mathrm{I}^{\mathbf{1}}$ are controlled at separate loci with $\mathrm{I}^{\mathbf{3}}$ epistatic to $\mathrm{I}^{\mathbf{1}}$. In this case the males must have been homozygous at the $\mathrm{I}^{1}$ locus; if they were not, typical would appear among the progeny.

To test which of these two alternatives applies, $\mathrm{I}^{3}$ males from $\mathrm{B} / 8 / 72$ and $\mathrm{B} / 9 / 72$ were crossed to typical females (B/I, 2 and 4/73). In all three crosses, $\mathrm{I}^{3}$ and typical segregate in approximate equality, which indicates that $\mathrm{I}^{\mathbf{3}}$ and $\mathrm{I}^{\mathbf{1}}$ must be allelomorphic; the only segregation possible if the genes controlling $\mathrm{I}^{3}$ and $\mathrm{I}^{1}$ were not alleles is $2\left(\mathrm{I}^{3}\right): 1\left(\mathrm{I}^{1}\right): \mathrm{I}(\mathrm{T})$.

Confirmation of the allelmorphic relationship of $I^{3}$ and $I^{1}$ is provided by the overall $2\left(\mathrm{I}^{\mathbf{3}}\right): \mathrm{l}\left(\mathrm{I}^{\mathbf{1}}\right): \mathrm{l}(\mathrm{T})$ segregation in $\mathrm{B} / 7 / 73$ whose parents were $\mathrm{I}^{\mathbf{1}}$ male $\times \mathrm{I}^{3}$ female. This in itself, however, is not conclusive in the absence of the information provided by B/1, 2 and $4 / 73$.

A further, more complicated and less likely, explanation of the segregation of $\mathrm{I}^{3}$ and $\mathrm{I}^{1}$ in $\mathrm{B} / 8 / 72$ and $\mathrm{B} / 9 / 72$ is that $\mathrm{I}^{3}$ and $\mathrm{I}^{\mathrm{I}}$ are the result of a modifying locus affecting insularia expression and converting $\mathrm{I}^{3}$ to $\mathrm{I}^{1}$ and vice versa. In this context family $\mathrm{B} / 9 / 74$ is crucial since its parents were a 
wild male $\mathrm{I}^{1}$ and a typical female from $\mathrm{B} / 4 / 73$, all of the insularia in which were $\mathrm{I}^{3}$. Thus the progeny of $\mathrm{B} / 4 / 73$ should on this hypothesis carry the modifier for $\mathrm{I}^{3}$ and, as a consequence, the insularia in B/9/74 should contain $I^{3}$. The absence of this morph from the family suggests that $I^{3}$ and $I^{1}$ are indeed allelomorphic and not due to the influence of a modifier acting on the locus controlling insularia.

\section{(ii) Genetic relationship of $I^{3}$ and carbonaria}

Table 2 contains details of the crosses relevant to this section. In order to establish whether $\mathrm{I}^{3}$ and $\mathrm{I}^{\mathbf{b}}$ are controlled by alleles at the carbonaria locus, two crosses were made $\left(B / 6 / 74\right.$ and $B / 10 / 74$ ) of female $I^{3}$ from $B / 4 / 73$ (table 1) to carbonaria males from backcross $(\mathrm{C}: \mathrm{T})$ families. The male parents were therefore $C \mathcal{T}$ heterozygotes.

\section{TABLe 2}

Families of Biston betularia used to examine the relationship of $\mathrm{I}^{3}$ and carbonaria. ${ }^{*} \mathrm{I}^{3} \mathrm{I}^{3}$ homozygotes, see text

\begin{tabular}{|c|c|c|c|c|c|c|c|c|}
\hline \multirow[b]{2}{*}{ Family } & \multicolumn{2}{|c|}{ Parents } & \multicolumn{5}{|c|}{ Progeny } & \multirow[b]{2}{*}{ Total } \\
\hline & Male & Female & $\mathrm{T}$ & 1 & 2 & 3 & C & \\
\hline $\mathrm{B} / 4 / 72$ & C ex Beddau & T ex Oxford & 10 & & & & 13 & 23 \\
\hline $\mathrm{B} / 9 / 73$ & $\mathrm{~T}$ ex $\mathrm{B} / \mathrm{l} / 72$ & $\mathrm{C}$ ex B $/ 4 / 72$ & 103 & & & & 98 & 201 \\
\hline $\mathrm{B} / 10 / 73$ & $\mathrm{~T} e x \mathrm{~B} / 10 / 72$ & $\mathrm{C}$ ex $\mathrm{B} / 5 / 72$ & 125 & & & & 122 & 247 \\
\hline $\mathrm{B} / 5 / 74$ & $\mathrm{I}^{3}$ ex $\mathrm{B} / 2 / 73$ & $\mathrm{I}^{3}$ ex $\mathrm{B} / 4 / 73$ & 66 & & & 149 & $77 *$ & 292 \\
\hline $\mathrm{B} / 6 / 74$ & $\mathrm{C}$ ex $\mathrm{B} / 9 / 73$ & $\mathrm{I}^{3}$ ex $\mathrm{B} / 4 / 73$ & 14 & & & 20 & 31 & 65 \\
\hline $\mathrm{B} / 10 / 74$ & $\mathrm{C} e \times \mathrm{B} / 10 / 73$ & $\mathrm{I}^{3}$ ex $\mathrm{B} / 4 / 73$ & 61 & & & 73 & 127 & 261 \\
\hline $\mathrm{B} / 6 / 75$ & $\mathrm{C}$ ex $\mathrm{B} / 6 / 74$ & $\mathrm{~T}$ ex B/9/74 & & & & 47 & 62 & 109 \\
\hline $\mathrm{B} / 7 / 75$ & $\mathrm{C} e x \mathrm{~B} / 10 / 74$ & $\mathrm{~T} e x \mathrm{~B} / \mathrm{l} / 74$ & & & 1 & 83 & 62 & 146 \\
\hline $\mathrm{B} / 9 / 75$ & $\mathrm{C}$ ex B $/ 10 / 74$ & $\mathrm{~T}$ ex B $/ 2 / 74$ & & & 3 & 64 & 57 & 124 \\
\hline $\mathrm{B} / 10 / 75$ & $\mathrm{~T} e x$ Beddau & $\mathrm{C}$ ex B $/ 6 / 74$ & & & & 60 & 87 & 147 \\
\hline $\mathrm{B} / 11 / 75$ & $\mathrm{~T}$ ex Beddau & $\mathrm{C} e x \mathrm{~B} / 10 / 74$ & 53 & & & & 60 & 113 \\
\hline $\mathrm{B} / 12 / 75$ & $\mathrm{C} e \times \mathrm{B} / 6 / 74$ & $\mathrm{~T}$ ex $\mathrm{B} / 11 / 74$ & & & & 52 & 51 & 103 \\
\hline
\end{tabular}

The progeny in both $\mathrm{B} / 6 / 74$ and $\mathrm{B} / 10 / 74$ segregated in the ratio $2 \mathrm{C}: 1 \mathrm{I}^{3}$ : 1T. This is possible whether $\mathrm{I}^{3}$ and carbonaria are controlled by alleles or not. Therefore six crosses $(\mathrm{B} / 6,7,9,10,11,12 / 75)$ were established to test this; in each cross carbonaria from $\mathrm{B} / 6 / 74$ or $\mathrm{B} / 10 / 74$ as mated with typical. If carbonaria and $\mathrm{I}^{3}$ are controlled by alleles at the same locus, two alternative segregations are possible:

$$
\begin{aligned}
& \mathrm{C}: \mathrm{T} \text { in equality, } \\
& \mathrm{C}: \mathrm{I}^{3} \text { in equality. }
\end{aligned}
$$

Similarly, if they are controlled by separate loci, with carbonaria epistatic to $I^{3}$, two segregations are possible:

$$
\begin{aligned}
& \mathrm{C}: \mathrm{T} \quad \text { in equality } \\
& \mathrm{G}: \mathrm{I}^{3}: \mathrm{T} \text { in the ratio } 2: 1: 1
\end{aligned}
$$

Thus either a $1 \mathrm{C}: 1 \mathrm{I}^{3}$ or a $2 \mathrm{C}: 1 \mathrm{I}^{3}: 1 \mathrm{~T}$ segregation would be diagnostic. From table 2 it is clear that both $1 \mathrm{C}: 1 \mathrm{I}^{3}$ and $1 \mathrm{C}: 1 \mathrm{~T}$ segregations occur among the six 1975 families; in none of them do three phenotypes occur. The $\mathrm{C}: \mathrm{I}^{3}$ segregation is possible only if $I^{3}$ and $C$ are allelomorphic, with carbonaria dominant to $\mathrm{I}^{3}$. 
The relationship of $\mathrm{I}^{3}$ to $\mathrm{C}$ is made more complicated by the segregation obtained in the progeny of $\mathrm{B} / 5 / 74$ which resulted from crossing male and female $I^{3} T$ heterozygote parents. It will be seen from table 2 that slightly more than a quarter of the offspring were scored as $\mathrm{C}$ and half as $\mathrm{I}^{3}$. The segregation in both sexes is close to $1: 2: 1$ (for both sexes combined, $\left.\chi^{2}(2)=0.952 ; 0.8>\mathrm{P}>0.7\right)$. It is certain from the provenance of the family that the "carbonaria" in B/5/74 are genetically $\mathrm{I}^{3}$ and from the segregation it seems likely that they represent the homozygous $\left(I^{3} I^{3}\right)$ genotype.

\section{(iii) Genetic relationship of $I^{1}$ and $I^{2}$}

In contrast with the segregation in families containing $\mathrm{I}^{1}$ and $\mathrm{I}^{3}$, those containing $\mathrm{I}^{1}$ and $\mathrm{I}^{2}$ (table 3 ) show a much less clear segregation when

TABLE 3

Families of Biston betularia used to examine the relationship of $I^{1}$ and $I^{2}$. The progeny of $B / 10 / 73$ fell within the range of $I^{1}$ and $I^{2}$ but were not categorised within it

\begin{tabular}{|c|c|c|c|c|c|c|c|c|}
\hline \multirow[b]{2}{*}{ Family } & \multicolumn{2}{|c|}{ Parents } & \multicolumn{5}{|c|}{ Progeny } & \multirow[b]{2}{*}{ Total } \\
\hline & Male & Female & $\mathrm{T}$ & 1 & 2 & 3 & $\mathrm{G}$ & \\
\hline $\mathrm{B} / 9 / 74$ & $I^{1}$ ex Beddau & $\mathrm{T}$ ex $\mathrm{B} / 4 / 73$ & 88 & 56 & 29 & & & 173 \\
\hline $\mathrm{B} / 10 / 74$ & $I^{1}$ ex Oxford & Tex Oxford & 96 & 68 & 26 & & & 190 \\
\hline B/13/75 & $\mathrm{T}$ ex Beddau & $\mathrm{I}^{2}$ ex $\mathrm{B} / 8 / 74$ & 76 & 10 & 58 & & & 144 \\
\hline $\mathrm{B} / 13 / 73$ & $I^{1}$ ex Beddau & $\mathrm{I}^{1}$ ex $\mathrm{B} / 10 / 72$ & 3 & 12 & 4 & & & 19 \\
\hline $\mathrm{B} / 8 / 73$ & $I^{1}$ ex Beddau & $I^{2}$ ex $B / 10 / 72$ & 97 & 125 & 152 & 38 & & 412 \\
\hline $\mathrm{B} / 11 / 73$ & $\mathrm{I}^{1}$ ex Beddau & $\mathrm{I}^{2}$ ex B/10/72 & 17 & 16 & 27 & 14 & & 74 \\
\hline $\mathrm{B} / 12 / 73$ & $I^{1}$ ex Beddau & $\mathrm{I}^{2}$ ex B/10/72 & 4 & 6 & 6 & & & 16 \\
\hline $\mathrm{B} / 11 / 74$ & $\mathrm{I}^{2}$ ex Beddau & $\mathrm{I}^{1}$ ex $\mathrm{B} / 7 / 73$ & 58 & 38 & 111 & 44 & & 251 \\
\hline $\mathrm{B} / 10 / 72$ & $I^{2} / 3 e x$ Oxford & $\mathrm{T} e x$ Oxford & & & & & & 514 \\
\hline $\mathrm{B} / 8 / 74$ & $\mathrm{I}^{2}$ ex Beddau & $\mathrm{T}$ ex $\mathrm{B} / 4 / 73$ & & 39 & 217 & 5 & & 261 \\
\hline
\end{tabular}

scored subjectively, as they have been here. Although the segregation of insularia to typical in these families is in accordance with Mendelian ratios, the segregation within the insularia category is not; this could in part be due to the mixed origin of most of the families (Oxford and South Wales). Nevertheless, some points do emerge which have a bearing on the genetics of moths falling within the range of variation encompassed by $\mathrm{I}^{1}$ and $\mathrm{I}^{2}$.

The 10 families in table 3 have been arranged into three groups:

(a) $\mathrm{I}^{1}$ or $\mathrm{I}^{2} \times \mathrm{T}$ where $\mathrm{T}$ appear in the progeny.

(b) $\mathrm{I}^{1}$ or $\mathrm{I}^{2} \times \mathrm{I}^{2}$ where $\mathrm{T}$ appear in the progeny.

(c) $\mathrm{I}^{2} \times \mathrm{T}$ where no $\mathrm{T}$ appear in the progeny.

In both $(a)$ and $(b)$ the presence of $T$ among the offspring indicates that all the insularia parents were insularia/typical heterozygotes, assuming that insularia is either dominant or epistatic to typical. On the same basis in (c) the male parents were insularia " homozygotes" in the sense that they had two, not necessarily identical, insularia alleles.

In the two families in which the insularia parent was $\mathrm{I}^{1}(\mathrm{~B} / 9 / 74$ and $\mathrm{B} / 10 / 74)$, there are more $\mathrm{I}^{1}$ than $\mathrm{I}^{2}$ among the offspring; the reverse is true in $\mathrm{B} / 13 / 75$, in which the insularia parent was $\mathrm{I}^{2}$. The difference in the relative proportion of $\mathrm{I}^{1}$ and $\mathrm{I}^{2}$ between the two types of family is highly significant $\left(\chi_{(1)}^{2}=59 \cdot 12\right)$. 
In $(b)$, those families where both parents were $I^{1} \mathcal{T}$ or $I^{2} T$ heterozygotes, two families (B/13/73 and B/12/73) contain only a small number of offspring. However, in three families the number of offspring is large and insects scored as $I^{1}, I^{2}$ and $I^{3}$ occur. The parentage of all three is similar, being $I^{1} \times$ $\mathrm{I}^{2}$; no $I^{3}$ allele is present in any of them. Just as $I^{3} I^{3}$ homozygotes may be darker than $I^{3} T$ heterozygotes (see above), it is tempting to suggest that some $I^{1} I^{2}$ individuals are being scored as $I^{3}$; that is to say, dominance within the insularia complex is not complete. However, if $\mathrm{I}^{1}$ and $\mathrm{I}^{2}$ were controlled by a pair of alleles then the expected segregation of genotypes in these families would be $1(T T): 1\left(I^{1} T\right): 1\left(I^{2} T\right): 1\left(I^{1} I^{2}\right)$. It is clear from table 3 that the offspring of $\mathrm{B} / 8 / 73\left(\chi^{2}{ }_{(3)}=69.38\right)$ and $\mathrm{B} / 11 / 74\left(\chi^{2}{ }_{(3)}=\right.$ $52 \cdot 83$ ) depart significantly from such a ratio though the offspring of $\mathrm{B} / 11 / 73$ do not $\left(\chi^{2}{ }_{(3)}=5 \cdot 46 ; 0 \cdot 2>\mathrm{P}>0 \cdot 1\right)$. This suggests that if distinct $I^{1}$ and $I^{2}$ alleles exist, then our scoring of insularia into the three categories does not correspond with the boundaries between genotypes.

Evidence supporting the above interpretation that insularia alleles may have an additive effect comes from one of the third group $(c)$ in table 3 , (B/10/72), the male parent of which was scored as being $\mathrm{I}^{2 / 3}$ (i.e. at the light extreme of $\mathrm{I}^{3}$, or dark extreme of $\left.\mathrm{I}^{2}\right)$. The large number of progeny were all insularia and distinctly lighter than the male parent. However, in the similar cross, $\mathrm{B} / 8 / 74$, the male parent is not darker than the progeny although it must have been carrying two insularia alleles.

\section{Discussion}

From this study it is clear that insects at the light $\left(\mathrm{I}^{1}\right)$ and dark $\left(\mathrm{I}^{3}\right)$ extremes of the insularia complex are controlled by alleles at the carbonaria locus. Re-examination of material kept from a previous investigation by one of us (Lees, 1968) reveals that the insularia in families B/1 and 5/67 of that study would here be scored as coming from neither extreme of the insularia range $\left(\mathrm{I}^{2}\right)$. This is confirmed by Steward's (1977) scoring of the 1968 material; it falls within his $M$ insularia category. It is probable that Clarke and Sheppard's (1964) material also represents this middle insularia class. If it does, then there is good evidence for three insularia alleles, all at the same locus as carbonaria.

Despite this evidence of three insularia alleles, the phenotypic gradation from typical to carbonaria appears subjectively to be more or less smooth. Although carbonaria shows complete dominance over both insularia and typical, dominance within the insularia complex is not complete and phenotypic boundaries are blurred. Kettlewell (1973) mentions that the typical form varies in its darkness, and that this variation is polygenically controlled. If some, or all, of the genetic and environmental factors affecting the darkness of typical also affect the expression of the insularia alleles, then this would have the effect of further blurring the distinction between separate insularia phenotypes.

Although there is considerable variation in the expression of typical between families used in this study, variation of typical within families is relatively small. There is no evidence of segregation of different typical phenotypes in any family; we therefore suggest that Kettlewell's (1973) $\mathrm{I}^{1}$ and $\mathrm{I}^{2}$ categories represent the genetic or environmental darkening of the 
TT genotype, rather than the effect of different alleles at the carbonaria locus.

Both this study, using a subjective scoring technique, and Steward's (1977) more objective analysis (which uses some of the same material), are in agreement that at the pale end of the insularia range there is a tendency for homozygotes to be darker than the corresponding insularia/typical heterozygotes. These findings corroborate Dr C. J. Cadbury's suggestion (in litt. and reported in Kettlewell, 1973, p. 140).

At the dark end of the insularia range, $I^{3} I^{3}$ homozygotes would seem to be darker than $I^{3} T$ heterozygotes and to be similar phenotypically to carbonaria. Although this is based on only one family $(\mathrm{B} / 5 / 74)$ in this study, and needs replicating, it does lend confirmation to an indication in Bowater's (1914) stock. His family 10.2 had a wild male parent which was scored as doubledayaria (= carbonaria). On crossing with a typical female, all the resulting progeny were dark insularia. This indicates that the male was homozygous for insularia and certainly darker than his offspring. However, on intercrossing two of the insularia progeny of $10 \cdot 2$, Bowater reports that their offspring were all insularia and no mention is made of segregation within this class, into paler and darker individuals.

If $I^{3} I^{3}$ homozygotes are found consistently to be phenotypically carbonaria, this would complicate the estimation of carbonaria gene frequencies in wild samples of the species, especially where insularia forms are common and carbonaria relatively rare, e.g. South Wales (Lees and Creed, 1975) and Scandinavia (Douwes et al., 1973).

The additive effect of insularia alleles is therefore supported by a variety of evidence, and this, coupled with the modifying effects of other loci increases the difficulty of further genetic analysis. However, it may be that, in future, scoring of all progeny for several "key" characters drawn from those used by Steward (1977) would increase the precision of this type of analysis.

Acknowledgments. - We thank Helen Lees for her careful rearing of numerous Peppered Moth families. Dr Richard Steward read an early draft of the paper and we are indebted to him for his comments on it. The first part of this work was supported by the Nuffield Foundation and the latter part by N.E.R.C.

\section{References}

Bowater, w. 1914. Heredity of melanism in Lepidoptera. 7. Genet., 3, 299-315.

CLARKE, C. A., AND SHEPPARD, P. M. 1964. Genetic control of the melanic form insularia of the moth Biston betularia (L.). Nature, 202, 215-216.

Douwes, P., PETERSEN, B., AND VESTERGREN, A. 1973. Melanism hos Biston betularius L. i. Danmark och södra Sverige (Lepidoptera). Entomologen, 2, 15-20.

KeTtrewell, H. B. D. 1958. A survey of the frequencies of Biston betularia (L.) (Lep.) and its melanic forms in Great Britain. Heredity, 12, 51-72.

кETtLEWEll, н. в. D. 1965 . Insect survival and selection for pattern. Science, 148, 12901296.

kettlewell, H. B. D. 1973. The Evolution of Melanism. Clarendon Press. Oxford.

LEES, D. R. 1968. Genetic control of the melanic form insularia of the Peppered Moth Biston betularia (L.). Nature, 220, 1249-1250.

LEES, D. R., AND GREED, E. R. 1975. Industrial melanism in Biston betularia: the rôle of selective predation. 7. Anim. Ecol. 44,67-83.

LEMCHE, H. 1931. Amphidasis betularia (L.) and its melanic varieties. 7. Genet., 24, 235-241. STEWARD, R. C. 1977. Multivariate analysis of variation within the insularia " complex" of the melanic moth Biston betularia. Heredity, 39, 97-109. 